\title{
Acting in a Tight Spot: Homi Bhabha's Postcolonial Politics*
}

\author{
Ilan Kapoor \\ York University, Toronto
}

\begin{abstract}
Homi Bhabha's writing on postcolonial agency foregrounds discursive subjection, yet retrieves subaltern subterfuge. It reconstructs a critical politics despite and because of hegemonic and orientalist representational systems. And it demonstrates the (im)possibility of a stable subject, but still manages to assert creative and performative agency. The article endeavours to analyse these feats and paradoxes, relying both on Bhabha's work and on some of the criticisms and controversies surrounding it.
\end{abstract}

\section{Introduction}

Poststructuralism faults modern, emancipatory politics for positing a stable and rational agent that can free itself from necessity/constraint. Pointing to the historical and socio-linguistic webs in which the agent is inescapably caught and positioned, and to the subject's unconscious slips and blind spots, poststructuralism tends to paint the picture of an unstable and not always rational agent. But in eschewing emancipatory politics, an important problem has been poststructuralism's propensity to reduce politics to critique and "resistance." The decentring of power, the deconstruction of the subject, tends to provide a weak and limited basis or justification for agency.

Homi Bhabha's work on (postcolonial) agency averts many of these problems, even as it relies on poststructuralism. It foregrounds discursive colonial authority and subjection, yet retrieves subaltern subterfuge. It reconstructs a critical politics ${ }^{1}$ despite and because of hegemonic and orientalist representational systems. And it demonstrates the (im)possibility of a stable, sovereign subjectthus problematizing the subject, at least in the Enlightenment sense of the term-but still manages to assert creative and performative agency.

I shall analyse these feats and paradoxes, relying both on Bhabha's writing and on a number of criticisms and controversies surrounding it. ${ }^{2}$ The latter will

${ }^{*}$ The author would like to thank the anonymous New Political Science reviewers for their valuable comments. And thanks to Kent Murnaghan, as always.

${ }^{1}$ I use the word "politics" in the general sense of collective or public action, recognizing that it may take multiple forms, i.e. electoral politics, deliberative democracy, revolutionary struggle, local resistance, and so on.

2 To date, I am unaware of any systematic analysis of Bhabha's politics: while there is a growing literature within postcolonial studies analysing his place in the literary critical field and some of the political dimensions of his work, there appears not to be any examination of his work done with regard to a politics; as for the field of political science, apart from Jeffrey T. Nealon's brief mention of Bhabha in Alterity Politics (see footnotes 38 and 48), I am unaware of any consideration of Bhabha's contributions to political theory. 
help identify the strengths of his notion of agency-especially its movement beyond resistance towards creativity - but also some of its limits and vulnerabilities -in particular its privileging of semiotics over materiality, and its relatively localized politics.

\section{From Orientalism to Agency}

Bhabha is a member of what has come to be known as the "Holy Trinity" of postcolonial theory, the remaining members being Edward Said and Gayatri Chakravorty Spivak. Bhabha builds on Said's work, but takes it in new directions. In Orientalism, ${ }^{3}$ Said draws on Foucault and Gramsci to link culture to imperialism: he argues that the Western episteme, supported by administrative, corporate and academic institutions, has enabled the West to simultaneously represent and dominate the Orient. His notion of "Orientalism" is thus the "enormously systematic discipline by which European culture was able to manage-and even produce-the Orient politically, sociologically, militarily, ideologically, scientifically, and imaginatively during the post-Enlightenment period." 4 While seminal and highly influential, part of the problem with this position is its tendency to depict an overly unifying and monolithic conception of Western cultural imperialism. The result is the reduction of the colonial subject to an "effect" of imperial discourse, as evidenced, for example, by the following statement: the "Orient was not (and is not) a free subject of thought and action." ${ }^{5}$ Said later recognizes the difficulty, ${ }_{1}$ but it is Bhabha (more than Gayatri Spivak ${ }^{7}$ ) who seizes upon it, underlining instead orientalism's discursive instability, and claiming that it need not be homogenous to be hegemonic. Indeed, Bhabha cites a passage from Orientalism that shows Said is aware of such instability but leaves the idea "underdeveloped."8

Bhabha links Saidian (and Foucauldian) discursivity to Lacan's psychoanalytic "lack" to show that orientalist representation or power is founded on, but

(Footnote continued)

This article is an attempt to fill these gaps, emphasizing, in general, the importance of postcolonial theory to political science, and in particular, the performative dimensions of Bhabha's work and its innovations over the poststructuralist politics of Foucault and Butler.

${ }^{3}$ Orientalism (London: Penguin, 1978, 1995 edn).

4 lbid., p. 3.

${ }^{5}$ Ibid.

${ }^{6}$ See, for example, Culture and Imperialism (New York: Vintage, 1993), p. xiii.

${ }^{7}$ While Spivak's work is certainly "political," she focuses much less than Bhabha on questions of agency, perhaps because her argument that there is no discursive space from which the subaltern can be heard makes it difficult for her (or the postcolonial critic) to retrieve or represent subaltern agency. As I will show, Bhabha's position that politics, while always contaminated by orientalist representations and institutions, can nonetheless be undertaken from within (the margins of) orientalism helps him retrieve subaltern agency and avert some of Spivak's problems. Cf. Spivak, "Can the Subaltern Speak?," in C. Nelson and L. Grossberg (eds), Marxism and Interpretation of Culture (Chicago: University of Illinois Press, 1988), pp. 271-313; and A Critique of Postcolonial Reason: Toward a Critique of the Vanishing Present (Cambridge: Harvard University Press, 1999), especially pp. $246 f f$.

${ }^{8}$ Homi K. Bhabha, The Location of Culture (London: Routledge, 1994), p. 73; henceforth, LOC.

${ }^{9}$ Homi K. Bhabha, "Translator Translated, W. J. T. Mitchell Talks to Homi Bhabha," Artforum (March, 1995), p. 114; henceforth, TT. 
undermined by, an ambivalence; the exercise of this power betrays a psychic process in which the colonizer fears, and so distinguishes himself from, the colonized "other," but simultaneously needs or desires the other to be recognized as master. Bhabha coins the term "hybridity" to characterize this ambivalent process, arguing that "in the very practice of domination the language of the master becomes hybrid" (LOC, p. 33). To illustrate the point, he analyses the colonial "stereotype," which he sees as an instance of the deployment of colonial authority. Stereotypes-the "noble savage," the "wily oriental"-enable colonial power to fix the colonized subject and justify the colonizer's superiority and authority. But Bhabha indicates how such constructions are (and must be) endlessly and anxiously repeated and doubled: the colonized is "both savage (cannibal) and yet the most obedient and dignified servant (the bearer of food); he is the embodiment of rampant sexuality and yet innocent as a child; he is mystical, primitive, simple-minded and yet the most worldly and accomplished liar" (LOC, p. 82; cf. pp. 66, 77, 85). This repetition, this doubling, exposes the instability and lack within colonial power.

Bhabha devotes substantial space to elucidating how hybridity can create openings for agency; as a result, his work takes on a distinctive and innovative political character (especially relative to Said's and Spivak's). For, discursive instability, while rendering the master's narrative contradictory and ambivalent, can also empower the subaltern to resist and interrupt it: "The ambivalence at the source of traditional discourses on authority enables a form of subversion, founded on the undecidability that turns the discursive conditions of dominance into the grounds of intervention" (LOC, p. 112). Bart Moore-Gilbert calls such subversion a kind of cultural and "psychological guerrilla warfare."10

Bhabha points out several instances of agency. In the essay, "Of Mimicry and Man," for example, he writes about the colonizer's attempt to promote a civilizing mission by creating "mimic men," that is, recognizable others who are "almost the same, but not quite" (LOC, p. 86). But this ambivalence ("same•/"not quite") is exploitable: mimicry easily serves as camouflage for menace or mockery, with the native threatening to deny (or denying) her master's desire for recognition or imitation. Similarly, in "By Bread Alone," the British stereotypically interpret a story -subsequently transformed into uncontrollable rumour by Indian villagers-about the villagers passing a chapati (flat bread) from hand to hand and village to village, as a warning sign of the impending 1857 "mutiny." The result is panic, and a disabling of British authority: "The iterative action of rumour, its circulation and contagion, links it with panic-as one of the affects of insurgency" (LOC, p. 200).

But probably the most famous Bhabhaian instance of "spectacular resistance" (LOC, p. 121) $)^{11}$ is to be found in the essay entitled "Signs Taken for Wonders." Relying on missionary records of the early 19th century, the essay discloses how an Indian catechist's bid to convert a group of villagers outside Delhi is subverted: the villagers refuse the sacrament and resist conversion on the grounds that the word of God comes from the mouth of a meat-eater, not a vegetarian. As Bhabha explains, "When the natives demand an Indianized

\footnotetext{
${ }^{10}$ Postcolonial Theory (London: Verso, 1997), p. 130.

11 Presumably, Bhabha uses "spectacular" to validate the subversive act, but also to draw attention to the act as "spectacle." I develop this idea later in the article.
} 
Gospel [or a "vegetarian Bible"!], they are using the powers of hybridity to resist baptism and to put the project of conversion in an impossible position" (LOC, p. 118). They contaminate the dominant discourse with their own suppressed knowledge (i.e. vegetarianism), and in so doing undermine colonial authority. In this sense, as Bhabha emphasizes, the episode is not just "an exchange between a muscular colonial Christianity that was keen to convert and an indigenous tradition that resisted conversion" but a "colonial antagonism" that produces a "supplementary" or "incommensurable" discourse as a site of "resistance and negotiation" (TT, p. 114).

It should be mentioned that Bhabha refrains from restricting his gloss to only colonial times; he refers as well to contemporary instances of political subversion. ${ }^{12}$ He validates, for example, the actions (during the early 1990s) of the British feminist group, Women Against Fundamentalism, when it used the Rushdie affair not to endorse either the Western liberal defence or the Islamist condemnation of the author, but to call public attention to a number of women's issues (e.g. access to education, gender inequality in the home, prostitution). Like that of the Delhi villagers, the women's agency consists in the creation of a "supplementary space": "Instead of taking the contradictions of the Rushdie affair head on and making it their project in some way to resolve or transcend them, they opened up the productive political site beside them, reconjugating, recontextualizing, translating the event into the politics of communities and public institutions" (TT, p. 114; cf. p. 90; LOC, p. 229).

\section{Agency with Subjection}

I want to reflect upon, and tease out several implications of, an important argument in Bhabha's thinking - that agency is possible only with subjection. The idea here is that we do not act under conditions of our own choosing; we act within a given discursive context. Speaking of agency as a kind of "translation," Bhabha says that "there must be a text for it to be translated. It may be a priority that is internally liminal or displaced, but there is something there that endows a particular kind of authorization and authentication" (TT, p. 83). There is no question of effecting change from somewhere "outside the text" (to echo Derrida); agency can happen no matter whether the given text is interdictive, repressive, stereotypical or orientalist. All of Bhabha's instances of agency arise precisely from the challenge of imperial authority, each instance a specific response, but also an impediment, to such authority. Hence, without discursive subjection, no agency is possible. Or, to quote Judith Butler, to whose work Bhabha sometimes refers (more on this point later): "There is only a taking

\footnotetext{
${ }^{12}$ For historical and contemporary applications of the notion of "hybridity," see Gyan Prakash, Another Reason (Princeton: Princeton University Press, 1999), which studies the relationship between science and colonialism in India, and the creation of hybrid forms of knowledge incorporating Western ideas and local cultural and religious practices; and Akhil Gupta, Postcolonial Developments (Durham: Duke University Press, 1998), which examines hybridity in local agricultural practices in modern India, and the conflicts between subalterns and transnational capital, technology and environmentalism.
} 
up of the tools where they lie, where the very 'taking up' is enabled by the tool lying there."13

Key to the notion of acting only with(in) a given discursive terrain is the idea of repetition. It is Derrida who points out that all utterances (or "speech acts") are repetitions (or "citational doubling"), so that when one articulates, one is actually re-articulating. ${ }^{14}$ Each iteration is never the same, moreover, because it is always marked by différance (contained in the very structure of language). This means that discourse is always already iterative, and each discursive iteration is differently articulated in different contexts. Bhabha says as much when he writes: "To recognize the differrance of the colonial presence is to realize that the colonial text occupies that space of double inscription, hallowed-no, hollowed-by Jacques Derrida" (LOC, p. 108). The implication for politics is that agency is precisely the performance, the acting out, of this repetition. So it is not by accident that Bhabha refers to "mimicry" as a strategy of both colonial subjection and subterfuge. ${ }^{15}$ "The menace of mimicry," he writes, "is its double vision which in disclosing the ambivalence of colonial discourse also disrupts its authority" (LOC, p. 88). Thus, the idea of "repetition" is a re-statement of the idea of "discursive instability," which as discussed earlier and as Bhabha just confirms, creates the opportunity for postcolonial agency. From the perspective of politics though, the notion of "repetition" adds to the earlier notion of "discursive instability" the important point that agency is restricted to only those openings and opportunities presented by discursive subjection.

But if discourse is always already repetition, and agency is the acting out of such repetition, then what difference does agency make ${ }^{16}$ In other words, what is agency's particular distinction? I think at least two such distinctions can be found in Bhabha's work. The first is agency's role precisely in exposing repetition, its "staging" of the ambivalence and contingency of authority. Bhabha calls this "desacraliz[ing] the transparent assumptions of cultural supremacy," "introduc[ing] a lack" or "exposing the limits of any claim to a singular or autonomous sign of difference-be it class, gender or race" (LOC, pp. 228, 119, 219). When the villagers transfigure the quaint and stereotypical chapati story into uncontrollable rumour (through repetition), they are revealing the fear their master's authority is founded on but is attempting to hide, pushing this fear to the point of panic; they are disarticulating and de-naturalizing the story or stereotype by exaggerating it to its absurd limits.

Critics such as Robert Young and Brett Nicholls appear to neglect this

\footnotetext{
${ }^{13}$ Gender Trouble: Feminism and the Subversion of Identity (New York: Routledge, 1990), p. 145. In many ways, both Bhabha and Butler are echoing (but also innovating, as I will point out later) Michel Foucault's assertion that the practices of the self are "not something that the individual invents by himself. They are patterns that he finds in his culture and which are proposed, suggested and imposed on him by his culture, his society, and his social group." In J. Bernauer and D. Rasmussen (eds), The Final Foucault (Cambridge, MA: MIT Press, 1988), p. 11.

${ }^{14}$ Jacques Derrida, "Signature Event Context," Margins of Philosophy, trans. A. Bass (Chicago: University of Chicago Press, 1982), pp. 307ff.

${ }^{15}$ Bhabha actually borrows the notion of mimicry from Lacan (see LOC, p. 90), but its parallels with Derrida's notion of repetition are unmistakable.

${ }^{16} \mathrm{Or}$, more precisely, if discourse is always already repetition with a difference (since each iteration is different), and agency is the performance of this repetition, then what particular difference does agency make?
} 
important feature of Bhabha's politics when they argue that his notion of agency can be easily co-opted by the hegemonic power. ${ }^{17}$ Nicholls, for example, complains that the "problematics of communication-the slippage of signs-is a general condition that 'is no respecter of persons,' slaves or masters. Moreover, if this is the case it is difficult to see how this problematic benefits the native yet at the same time thwarts the process of domination." ${ }^{18}$ Bhabha would agree that repetition or discursive instability is the "respecter of no persons," for as just noted, iteration is part and parcel of both dominant discourse and subaltern agency. The crucial difference, however, is that subaltern agency is about exposing the doubling and constructedness of discourse/power, while domination, to be domination, is about fixing or hiding them. (It is difficult to see how prejudice, for example, can maintain itself if its artifice and contingency are exposed, no matter who does the exposing.)

Agency's second distinction is that, while "repeating the lessons of the masters," it "changes their inflections." 19 Bhabhaian politics are a kind of variation on a (discursive) theme: mimicry is not just returned, it is returned as mockery; colonial Christianity is not just re-appropriated and re-interpreted, it is mis-appropriated, mis-interpreted, mis-translated, estranged. Often, as the "Delhi villagers" example shows, politics involves only minor tinkering. Bhabha speaks of "small differences" and "slight alterations and displacements" as "often the most significant elements in a process of subversion or transformation" (TT, p. 82) ${ }^{20}$ These alterations are "most significant" because they produce supplemental positions: the villagers' "vegetarian Bible" is not simply a new variation, it is an incommensurable position, an irresolvable riddle that flummoxes colonial authority. Bhabha calls this a "Third Space" (LOC, p. 37), that is, a position that is made possible by discursive subjection, but cannot be directly derived from it. It is a non-dialectical space standing in between the binary structures of orientalist representations and imperial power. In this sense, agency's "difference" is about negotiating "polarizations without acceding to their foundational claims" (TT, p. 83), "both challenging the boundaries of discourse and subtly changing its terms" (LOC, p. 119).

I think it is important to note that by retrieving these creative possibilities in agency, Bhabha is innovating Foucauldian politics. To Foucault's "there are no relations of power without resistance," ${ }^{21}$ Bhabha appears to be responding with "there are no relations of power without agency." This slight inflection-true to Bhabhaian style--provides a significant positive dimension to Foucauldian politics, making it more than just the "effect" of discourse. For Bhabha as for

\footnotetext{
${ }^{17}$ Robert Young, Colonial Desire: Hybridity in Theory, Culture and Race (New York: Routledge, 1995); and Brett Nicholls, "Disrupting Time: Post-Colonial Politics in Homi Bhabha's The Location of Culture," Southern Review 30•1 (1997), pp. 4-25.

${ }^{18}$ Nicholls, "Disrupting Time," p. 19.

${ }^{19}$ Homi K. Bhabha, "Freedom's Basis in the Indeterminate," and "Discussion," in J. Rajchman (ed.), The Identity in Question (London: Routledge, 1995), p. 54; henceforth, FB.

${ }^{20}$ Hannah Arendt points out, in this regard, that "action, though it may proceed from nowhere, so to speak, acts into a medium where every reaction becomes a chain reaction ... the smallest act in the most limited circumstances bears the seed of the same boundlessness, because one deed, and sometimes one word, suffices to change every constellation." In The Human Condition (Chicago: University of Chicago Press, 1958), pp. 190-191.

${ }^{21}$ Michel Foucault, Power/Knowledge, C. Gordon (ed.) (New York: Pantheon, 1980), p. 142.
} 
Foucault, power is productive, but whereas for the latter the political response to subjection is a negative and restricted "resistance," for the latter, the response is a more positive and creative agency. Not surprisingly, Bhabha states that power is about "incitement and interdiction" (LOC, p. 72, emphasis mine), "making possible and making trouble, both at once" (TT, p. 110, emphasis mine). The "mimic men" and the Women Against Fundamentalism are not only resisting, they are also engaging in subterfuge and mis-recognition that produce a Third Space.

\section{Implications for "Native" Representation and Historiography}

The notion that agency happens only within discourse is a conundrum for identity politics, since it implies that the identity you call upon for agency is restricted to an imposed script: you can construct it exclusively from the signification system of the colonizer or hegemon. This is a difficult position to defend in the face of many nationalist ${ }^{22}$ or decolonization movements, which aim at mitigating the native's estrangement from her/his own culture by recovering a "pure" or "indigenous" history and regaining a sense of national pride. But like Fanon and Spivak, from whom he often draws on this question (e.g. LOC, pp. 40ff., 183-184), Bhabha is critical of these types of attempts. He argues that the nationalist, the politician and the cultural critic alike can neither extricate themselves from their position in postcolonial history, nor resort to a language uncontaminated by orientalism or imperialism: they have no "immediate access to an originary identity or a 'received' tradition" (LOC, p. 2).

This argument about the (im)possibility of a "nativist" position is controversial for some historiographers. ${ }^{23}$ These critics question the extent to which postcolonial theorists such as Bhabha can maintain that native identity is tied to colonial discourse. Nicholas Thomas, for example, declares that Bhabha "excludes the possibility that 'natives' often had relatively autonomous representations and agendas, that might have been deaf to the enunciations of colonialism, or not so captive to them that mimicry seemed a necessary capitulation." ${ }^{24} \mathrm{He}$ concludes that Bhabha's position ends up "diminish[ing] or deny[ing] difference." ${ }^{25}$ Similarly, O'Hanlon and Washbrook invoke Jameson and Huyssen to argue for a "labour of remembrance," a historical understanding that allows agents to "orient themselves." 26 Summarizing these arguments, Meagan Vaughan writes that "colonial discourse theory completely neglects and negates the pre-colonial." 27

Although Bhabha does not directly respond to these criticisms, it is possible

\footnotetext{
${ }^{22}$ Bhabha has in mind right-wing religious nationalist movements.

${ }^{23}$ Rosalind O'Hanlon and David Washbrook, "After Orientalism: Culture, Criticism, and Politics in the Third World, " Comparative Studies in Society and History 34 (1992), pp. 141-167; Megan Vaughan, "Colonial Discourse Theory and African History, or Has Postmodernism Passed Us By?," Social Dynamics $20 \bullet 3$ (1994), pp. 1-23; and Nicholas Thomas, Colonialism's Culture (Princeton, NJ: Princeton University Press, 1994).

${ }^{24}$ Colonialism's Culture, p. 57. See also Jean Comaroff and John Comaroff, Of Revelation and Revolution: Christianity, Colonialism and Consciousness in South Africa (Chicago: Chicago University Press, 1991).

${ }^{25}$ Colonialism's Culture, p. 51.

26 "After Orientalism," p. 153. See also Vaughan, "Colonial Discourse Theory," p. 5.

27 "Colonial Discourse Theory," p. 7.
} 
to draw out answers from his work. To start, there is an important passage to consider in The Location of Culture:

$[T]$ he text of transparency inscribes a double vision: the field of the "true" emerges as a visible sign of authority only after the regulatory and displacing division of the true and the false. From this point of view, discursive "transparency" is best read in the photographic sense in which a transparency is also always a negative, processed into visibility through the technologies of reversal, enlargement, lighting, editing, projection, not a source but a re-source of light. Such a bringing to light is a question of the provision of visibility as a capacity, a strategy, an agency. (LOC, p. 110)

Colonial discourse is thus a kind of "negative transparency" through which identity and agency are constructed. To wit: the Delhi villagers assert a "native" identity (e.g. vegetarianism) but only through the imposed transparency of colonial Christianity. Far from neglecting or ignoring the precolonial, then, Bhabha is validating or "tracing" it (in the Derridean sense); his idea of agency is decidedly about the possibility of suppressed knowledges coming to the fore, but only within-or more accurately, between-the contours of hegemonic representations. The native can and does have a degree of autonomy and a labour of remembrance, but only in the liminal spaces opened up from inside the dominant discourse.

The historiographers affirm the "relative autonomy" of identity and remembrance vis-à-vis the hegemonic discourse, but in so doing they appear not to be taking "hegemony" seriously enough. The encounter between colonizer and colonized is not one of equals; it is not a contest of multiple discourses on a "level playing field" (so to speak). Indigenous identity must be mediated through colonial representational systems because the latter are dominant. Of course, for Bhabha the latter are not fully dominant, and it is because they aren't that agency is possible: "agency requires a grounding," he writes, "but it does not require a totalization of those grounds" (LOC, p. 185). Moreover, native identity or remembrance cannot avoid, or be "deaf to," hegemonic discourse. After all, it is when the hegemon flexes his muscle that a response is needed. As Bhabha says, power forces you to "put yourself elsewhere," or "be pushed into another space or time from which to revise or review the problem" (TT, p. 83). Thus, it is precisely when the native is faced with a challenge that $s /$ he must construct and assert her/his memory or identity; and per force, s/he can do so only in relation to, and in the terms of, the hegemonic discourse.

\section{Implications for Politics}

I would like now to draw out three of the specifically political implications of tying agency to discursive subjection. The first is Bhabha's implied note of caution to those whose response to subjection is direct opposition. He warns that overcoming domination, far from getting rid of it, often occasions its mere reversal (FB, p. 55). The ensuing message to revolutionaries (Marxist or otherwise), for example, is that a violent counter-force to imperialism is likely to result in the perpetuation of violence and the replacement of one domination by another. The message to nationalists (like those mentioned earlier) is that harkening back to a "pure" native identity or "true" national history yields a 
reverse ethnocentrism or racism; it buys into and reproduces in another form the very oppressor's binary structure of signification (us/them, white/black, civilized/uncivilized) that it is trying to avert. Bhabha endorses the views of Fanon, whom he believes is cognizant of the need for a national culture, but is "far too aware of the dangers of the fixity and fetishism of identities within the calcification of colonial cultures to recommend that 'roots' be struck in the celebratory romance of the past or by homogenizing the history of the present" (LOC, p. 9; cf. pp. 152-153, 157). Given, then, that the eradication of one disciplinarity produces another, and granted the hazards of direct opposition to power (supposedly) "from without," it is not surprising to find Bhabha advocating an agency that displaces, interrupts and estranges power only from within.

A second implication, following especially from the notion of agency as a form of repetition, is that Bhabha does away with a "pro-active" conception of politics. He does away with it, that is, at least in the Enlightenment sense of positing a sovereign or calculating agent who can plan ahead autonomously and ex nihilo. For Bhabha, politics cannot happen "ahead," as it is always already an "after," an iteration of the discourse that has both preceded it and made it possible. Of course, this does not mean that the agent cannot plan, only that her/his planning is necessarily a contingent/contingency plan. Bhabha is merely reinforcing here the poststructuralist critique of any illusion of politics as a "total break," of action taking place in a vacuum.

A final implication, which Bhabha emphasizes often, is that agency is a form of "negotiation" (LOC, pp. 25, 38, 185, 191). That action happens iteratively and within the hegemonic discursive field means there is a degree of mutuality and complicity between the agent and the hegemon, even if each may want to deny it. The agent must play with the cards $\mathrm{s} /$ he is dealt, and the hegemon, despite the appearance of absolute strength, needs or desires the subaltern. ${ }^{28}$

What is compelling about Bhabha's argument here is the idea that, in the semiotic/discursive realm, the oppressed can act subversively in spite of the master's dominance. The negotiative aspect of the encounter, even in the face of unfavourable odds, is what allows for subaltern agency. Hence Bhabha notes, "Forms of popular rebellion and mobilization are often most subversive and transgressive when they are created through ... cultural practices" (LOC, p. 20, emphasis mine). The problem, however, is that he does not support this claim. As I have argued elsewhere, ${ }^{29}$ to say that cultural practices are "most subversive"-presumably relative to material ones - he would need to supply a comparative political economy analysis. Not only does he not do so, he tends to omit the material realm in his analysis of agency. His instances of agency are

\footnotetext{
${ }^{28}$ Note that the master's "desire" need not be merely for recognition (by the colonial subject); it can also be sexual, and is most often gendered. Bhabha implies this, although his work does not dwell upon it. For readings of sexualized colonial desire (gendered, eroticized/exoticized, repressed, homoerotic), see Frantz Fanon, Black Skin, White Masks (New York: Grove Press, 1967, 1982 edn); Anne McClintock, Imperial Leather: Race, Gender and Sexuality in the Colonial Contest (New York: Routledge, 1995); Grant Parsons, "Another India: Imagining Escape from the Masculine Self," in Phillip Darby (ed.), At the Edge of International Relations: Postcolonialism, Gender and Development (London: Pinter, 1997); and Irvin Cemil Schick, The Erotic Margin (London: Verso, 1999).

${ }^{29}$ Ilan Kapoor, "Capitalism, Culture, Agency: Dependency Versus Postcolonial Theory," Third World Quarterly 23. 4 (2002), pp. 647-664.
} 
restricted to semiotic transactions (i.e. resistance to imitation, stereotypes, religious conversion), disregarding material ones (e.g. anti-capitalist subversion, protests against unequal pay or inhuman working conditions). Even in his analysis of semiotic transactions, he makes no mention of the differential socio-economic positioning of his interlocutors, ignoring how the power inequality between them may affect their negotiating abilities.

It seems to me that Bhabha's argument is not necessarily undermined by this neglect, since even social/material status must be semiotically represented in any political encounter, thus being subject to discursive instabilities and subterfuge. But as Benita Parry points out, what is missing is an analysis of the relationship between materiality and agency and the limits material inequality impose on subaltern "negotiation." ${ }^{30}$ For example, will the hegemon's threat of economic retaliation, or the subaltern's relative lack of access to education or health, not weaken to some extent the latter's ability to engage in semiotic subterfuge? Unfortunately, Bhabha leaves these types of questions unanswered. $\mathrm{He}$ also says little about the negotiative possibilities among colonized subjects. In the Delhi incident, for example, the villagers' action could be read as privileged, since vegetarianism in many parts of India is often practised by the dominant castes (some lower castes and many non-Hindus, especially the minority Muslim communities, are meat-eating). ${ }^{31}$ As Bhabha neither provides us with a social context nor takes it into account in his theorizing on the incident, it is impossible to tell whether such political action is reserved for colonized elites or open to all colonized subjects/subalterns, or indeed whether or not the former are likely to be more effective than the latter in semiotic challenges to the colonizer.

\section{Agency without a Subject?}

Several critics have taken Bhabha to task for making agency impersonal, involuntary and robotic. ${ }^{32}$ They suggest, in fact, that he "vacillates," at times positing a "transitive" and at others an "intransitive" mode of agency. Certainly, Bhabha's use of terms such as "indeterminacy" and "deliberate" (LOC, pp. 205, 209) when referring to subaltern politics can leave one with this impression. Hence Moore-Gilbert et al. state that he "fudges the question of whether the kinds of 'active' resistance he outlines are actually (self)conscious or not, so that it remains unclear whether the agency of the colonized/postcolonial subject can be consciously purposive and programmatic." ${ }^{33}$ Moreover, Young and Parry wonder why Bhabha's subject, in the absence of self-consciousness, would want to act, and on the basis of what normative or moral horizon s/he would be moved to act. ${ }^{34}$ Young asks: "what political status can be accorded the subver-

\footnotetext{
30 "Signs of Our Times," Third Text 28: 9 (1996), p. 21.

${ }^{31} \mathrm{I}$ am grateful to one of the anonymous NPS reviewers for pointing this out to me.

${ }^{32}$ Robert Young, White Mythologies: Writing History and the West (London: Routledge, 1990), p. 152; Moore-Gilbert, Postcolonial Theory, pp. 130ff.; and Parry, "Signs of Our Times," pp. $16 \mathrm{ff}$.

${ }^{33}$ Bart Moore-Gilbert, Gareth Stanton and Willy Maley (eds), Postcolonial Criticism (London: Longman, 1997), p. 38.

${ }^{34}$ Young, White Mythologies, p. 152; and Parry, "Signs of Our Times," p. 15. See also O'Hanlon and Washbrook, "After Orientalism," pp. 152-153; and Vaughan, "Colonial Discourse Theory," p. 5.
} 
sive strategies that Bhabha articulates?" ${ }^{\prime 35}$ Thus, if we are to take these critics at their word, not only is Bhabha's notion of agency possible despite or because of subjection, but it also takes place without a definable grounding or subject.

I would like to suggest that, indeed, these critics are right, but they miss the performative dimension of Bhabha's position. They appear to be in search of what may be called an "expressive" agency, ${ }^{36}$ one that reveals an ontological subject with intentions, morals and consciousness, as opposed to a "performative" agency, in which these subjective qualities are "acted out" by the agent, not given cut-and-dried before hand. Judith Butler and Hannah Arendt are the main proponents of this notion of performativity, and it is helpful to consider briefly what they have to say about it before returning to Bhabha.

Butler speaks of the gendered body as performative, in the sense of a "forced reiteration of norms." 37 Invoking the concept of "repetition" (which as mentioned earlier, Bhabha also invokes), she shows how gender is a socially-imposed or discursive code that is responded to and performed. Drawing on drag, she also shows how performative agency includes (although is not to be equated with) performance, in this case a parody of the idea of a "fixed" or "original" female or male identity. ${ }^{38}$ Her overall point though is that, in acting, the subject "has no ontological status apart from the various acts which constitute its reality. ${ }^{39}$ Like the stage actor performing a scripted role, the agent is subjectivized in the very performance of the (socially interpellated) act.

While Arendt does not, of course, share the same intellectual horizons as Butler (Arendt's performativity is indebted, in particular, to Greek/Aristotelian political thought, Butler's to Foucauldian and Derridian thought through discursivity and speech-act theory). Arendt puts forth a similar conception of the subject/agent. For her, agency and subjectivity are only palpable in the public realm. The self is multiple and fragmented-a private self, labouring to meet survival needs, working to provide for life's luxuries, carrying out innocuous conversations with itself-before it enters the public arena; but it coheres once it engages in public performance and debate, that is, once it transforms itself from individual into citizen. ${ }^{40}$ According to Arendt, to act in public is of prime importance: it is "to begin," persona. As Bonnie Honig writes, "There is no 'being' behind this [Arendtian] doing. The doing, the performance, is everything." 42

\footnotetext{
${ }^{35}$ White Mythologies, p. 152.

${ }^{36}$ Butler, Gender Trouble, p. 141. See also Bonnie Honig, "Toward an Agonistic Feminism: Hannah Arendt and the Politics of Identity," in J. Butler and J. Scott (eds), Feminists Theorize the Political (New York: Routledge, 1992); and Jessica J. Kulynych, "Performing Politics: Foucault, Habermas, and Postmodern Participation," Polity 30•2 (1997), p. 321.

${ }^{37}$ Bodies that Matter: On the Discursive Limits of "Sex" (New York: Routledge, 1993), p. 94, see also p. 225.

${ }^{38}$ Gender Trouble, p. 138. Butler distinguishes "ironic performance," where the actor can choose a role at will, from performativity, which is about responding to forced social norms. See Bodies that Matter, pp. 3, 24; and Jeffrey T. Nealon, Alterity Politics (Durham, NC: Duke University Press, 1998), p. 23.

${ }^{39}$ Gender Trouble, p. 136.

${ }^{40}$ The Human Condition, pp. 7-9, 175-181. See also Honig, "Toward an Agonistic Feminism," p. 219.

${ }^{41}$ The Human Condition, p. 177.

42 "Toward an Agonistic Feminism," p. 217.
} 
Bhabha has many affinities with both Butler and Arendt. He refers to their work several times (LOC, pp. 188-190, 219; TT, p. 110), and especially to Arendt on the relationship between subjectivity and agency. His writing is strewn with the words "performance" or the "performative," speaking, for example, about the "postcolonial performance of repetition" (FB, p. 52) or the "performative nature of differential identities" (LOC, p. 219). But it is in "DissemiNation" that he elaborates what he means. In the essay, he distinguishes between the "pedagogical" and the "performative," the former denoting the nation's narrative authority "signifying the people as an a priori historical presence, a pedagogical object," and the latter the "people constructed in the performance of a narrative, its enunciatory 'present' marked in the repetition and pulsation of the national sign" (LOC, p. 147). The distinction is similar to the one we broached earlier between the iterative, hegemonic discourse that attempts to fix subaltern identity, and (performative) agency that acts out the discourse but exposes its doubling and contingency. The important point for our present purposes though is that, like Butler and Arendt, Bhabha conceives of the subject as being performed in the "enunciatory present marked in the repetition." The people-as-subject, for him, only emerge out of the nation when they act as political agents, parading the heterogeneity and ambivalence (as opposed to the static "pedagogical object") that is the nation.

As is the case with Butler and Arendt, there is an unmistakable theatricality attendant in Bhabha's performativity. He refers to the agency of the Delhi villagers as "spectacular resistance" (as noted earlier), and in other instances directs our attention to a "spectatorial distance" or how "the contingency of the subject as agent is articulated in a double dimension, a dramatic action" (LOC, pp. 244, 186). Frequently, his notion of agency is both a "show" and a "showing up," 43 as witnessed by the mischief-making, "messing around" and meddling that his agents engage in. The comedic and parodic elements of his narrative help demonstrate to the readers/audience-and draws them into-the agent's campaign to scrutinize, mock and/or interrupt the hegemonic discourse. Like all (political) theatre, the comedic is mixed in with the dramatic: as Arendt underlines $^{44}$ and Bhabha rehearses (LOC, pp. 12-13), a performance is always risky and unpredictable, with the protagonists never sure of the impact of their words and actions-"will I succeed?," "will s/he respond?," "will the audience care?" Thus, the native and British circulation of the chapati story has no control over how, or even if, the story turns into rumour or panic. What such unpredictability reveals once again though, as Jessica Kulynych points out, is "the contingency of both subjectivity and subjection." 45

We are now in a position to better answer Bhabha's critics: his alleged vacillation over whether agency is transitive or intransitive is to be understood in the context of performativity. For Bhabha, the subject is interpellated in action: there is no subject before or after but only when s/he becomes an agent. It is no wonder, then, that on the very pages that he is accused of wavering between "indeterminate" and "deliberate" agency, he repeatedly refers to the "performative" (compare LOC, pp. 200, 202, 204, 209). The critics are in search

\footnotetext{
${ }^{43}$ Kulynych, "Performing Politics," p. 323.

${ }^{44}$ The Human Condition, pp. 180, 191.

45 "Performing Politics," p. 324.
} 
of a pre-formed rather than a performed subject; they seek either a transitive or intransitive subject, but miss that $\mathrm{s} /$ he is always already in transit. The existence of an ontological subject is an illusion ${ }^{46}$ which performative agency helps expose and disrupt. Implicit here again is Bhabha's critique of the modern conception of a sovereign and transcendent politics: "Despite all the talk about fragmented subjects, floating signifiers, structural totalities, and post-Modern 'spaces,' " he says, "there is an interesting paradoxical return to traditional articulations of consciousness-intention-action" (FB, p. 118). Moreover, when the critics ask about the normative basis of Bhabhaian agency, they appear to have in mind an oppositional or argumentative politics, in which the subject expresses an already formed "ethics" or imports it from "outside," something which we have already noted Bhabha is trying to resist. Kulynych explains and summarizes it well:

[T] he performative protestor does not argue against the state, he mocks it. The protestor works at the margins of the discourse, utilizing puns and jokes and caricature to "expose" the limits of what is being said. Thus, performative resistance, when considered as critique, does not need to tell us what is wrong, rather it reveals the existence of subjection where we had not previously seen it ... [P]erformativity is not about normative distinctions. We bring normativity to our performances as ethical principles that are themselves subject to resistance. By unearthing the contingency of the "self-evident," performative resistance enables politics. Thus, the question is not should we resist (since resistance is always, already present), but rather what and how we should resist. ${ }^{47}$

Of course, Bhabha's performativity does more than "resist." It produces a Third Space. In this, it must be mentioned, he appears to push performativity further than Butler (or Kulynych). Although he shares much with Butler ${ }^{48}$ (more perhaps than with Arendt, who does not have a notion of discursivity), his postcolonial lens helps him open up the creative possibilities of a performative agency. Several analysts ${ }^{49}$ have warned against the Butlerian tendency to view agency mainly as a negative and constrained act of resignification. The reason, according to them, is that Butler too narrowly conceives of the symbolic sphere, restricting her analysis principally to gender identity and representations of sexuality. According to Lois McNay, Butler thus "fails to draw out fully ... the

\footnotetext{
${ }^{46}$ An illusion that Butler says we construct because of a "stylized repetition of acts" (Gender Trouble, p. 140).

47 "Performing Politics," p. 323.

${ }^{48}$ In Alterity Politics, Jeffrey Nealon dismisses Bhabha's notion of performativity (and champions Butler's) because (puzzlingly) he believes it to be "predicated on the possibility of some kind of wholeness or plenitude" (p. 10) that results in resentment and impedes a politics of alterity. Nealon argues that Butler's performativity, derived from Foucault/Derrida, is more conducive to alterity politics because of the implied idea of repetition/response. I think Nealon misrepresents Bhabha, in part because he relies on the reading of only one essay ("DissemiNation"). As I argue, Bhabha is close to Butler (closer than Nealon suggests), with the idea of repetition/response very explicitly (and repeatedly!) invoked in his work (i.e. Nealon sees only the Lacanian and misses the Derridean and Foucauldian in Bhabha).

${ }^{49}$ Seyla Benhabib, "Subjectivity, Historiography and Politics," in S. Benhabib, J. Butler, D. Cornell and N. Fraser (eds), Feminist Contentions: A Philosophical Exchange (London: Routledge, 1995); Nancy Fraser, "False Antitheses," and "Pragmatism, Feminism, and the Linguistic Turn," in Feminist Contentions; Moya Lloyd, A Feminist Politics of Difference (London: Sage, 2002); Lois McNay, "Subject, Psyche and Agency: The Work of Judith Butler," Theory, Culture and Society 16.2 (1999), pp. 175-193; and McNay, Gender and Agency: Reconfiguring the Subject in Feminist and Social Theory (Cambridge: Polity Press, 2000).
} 
ways in which the symbolic realm is composed of conflicting values and resources which may be actively, and sometimes creatively, appropriated by actors to institute new value systems and new forms of collective identity." 50 As the previous sections in this article have underlined, Bhabha does precisely what critics like McNay say Butler should-he conceives of discursive instability in such a way that it becomes possible for agents not only to recast the hegemonic discourse (e.g. mimicry/mockery) but to estrange it in multifarious ways by retrieving from within it suppressed and "foreign" meanings that yield supplemental representations (e.g. the vegetarian Bible).

\section{Agonistic Difference}

Bhabha's conception of politics as performative allows him to do a number of things, one of which is to valorize heterogeneity. Différance, as we have seen, is integral to the very hybridity and iterability of discourse, and agency's role is to help reveal it. Like Arendt, who sees the public arena as both thriving on difference and holding it together agonistically, ${ }^{51}$ Bhabha aims at an agonistic cultural pluralism, that is, a (Third) space that preserves "the enunciative boundaries of a range of other dissonant, even dissident histories and voiceswomen, the colonized, minority groups, the bearers of policed sexualities" (LOC, p. 5). This objective is particularly important to him (and to postcolonialism), given imperialism's past and continuing attempts to suppress heterogeneity in the name of "modernity," "civilization," "development" or "revolution." The creation of an agonistic Third Space is not about trying to sublate or transcend imperialism (i.e. it is not a "third term" or synthesis); it is a non-dialectical location created in the interstices of imperialism, where the "stubborn chunks" and the "incommensurable" and "untranslatable" elements are articulated (LOC, pp. 219, 227).

One of the notable ways in which Bhabha marks différance is by deploying the notion of the "time-lag." Partly, he is making us critically aware here of the temporal disjunctures within modernity, so that, for example, at the same time that 19th-century Britain was laying the groundwork for democracy and citizenship at home, it was engaging in economic exploitation, authoritarianism and human rights abuse in its colonies (something similar may be said of the current neocolonial relationships between the First and Third Worlds). And partly, Bhabha is attempting to deconstruct teleological time, so that Western modernity $^{52}$ does not pose as History, and non-Western "tradition(s)" are en-

\footnotetext{
50 "Subject, Psyche and Agency," p. 187.

51 The Human Condition, pp. 57, 176.

${ }^{52}$ It should be noted that Bhabha is sceptical not only of modern time, but postmodern time/space as well. For example, he takes Foucault to task for privileging time over location or space in his historiography (cf. Nicholls, "Disrupting Time," pp. 5ff.). That is, according to Bhabha, even as Foucault espouses a discontinuous and multi-perspectival view of history, his view of space-European space-is single and continuous. Foucault's time, no matter its discontinuity, is thus constructed in terms of fixed European space. Bhabha takes issue, in particular, with Foucault's reading of the French Revolution, and asks: "what if the 'distance' that constitutes the meaning of the 'Revolution' as sign, the signifying lag between event and enunciation, stretches across the Place de la Bastille or the rue des Blancs-Monteaux, but spans the temporal difference of the colonial space ... The Eurocentricity of Foucault's theory of cultural difference is revealed in his insistent spatialization
} 
countered on their own terms and time(s). Always reading the world in binary terms (First/Third World, developed/underdeveloped), ignores the existence of Third Worlds in the First (e.g. the colonial conditions of current North American native communities, the existence of substantial non-European migrant communities in Europe, significant regional economic disparities within Western countries) and First Worlds in the Third (e.g. "global" and cosmopolitan cities in the South, the development of cutting-edge technologies in India, the availability of universal health care in Cuba). It also ignores the different temporalities of decolonization: for instance, the fact that Latin America has experienced a longer period of formal independence compared to Africa.

"Time-lag" thus acts as a kind of critique of the universalization of EuroNorth American cultural priorities, as well as a validation of those political attempts to articulate differential and post-orientalist knowledges. Let me quote Bhabha here:

The power of the postcolonial translation of modernity rests in its performative, deformative structure that does not simply revalue the contents of a cultural tradition, or transpose values "cross culturally." The cultural inheritance of slavery or colonialism is brought before modernity not to resolve its historic differences into a new totality, nor to forego its traditions. It is to introduce another locus of inscription and intervention, another hybrid, "inappropriate" enunciative site, through temporal split-or time-lag-that I have opened up ... for the signification of postcolonial agency. (LOC, pp. 241-242)

\section{Democratizing Politics}

Following Foucault, Bhabha's examination of the strategies of power leads him to identify them not just at macro/global levels (in the form of imperialism or orientalism), but most especially at local levels. He sees the "microtechnics of power" (LOC, p. 116) at work in the far-flung corners of the globe. But on the other side of power's sweeping reach lie multiple local responses and acts of resistance-which is what his notion of performative politics aims at recognizing. Kulynych notes that performativity is not "intentional, rational, and planned; it may be accidental, impulsive, and spontaneous." 53 Indeed, for Bhabha it is: his instances of agency capture people's everyday encounters with, and challenges to, power. Most often, the acts happen in spaces hidden from view, spaces that would usually be considered "marginal," "vulgar" or "banal." Most often, too, the acts are performed by the subaltern, the displaced, marginals, minorities. For Bhabha, it is they who are (and have been) at the forefront of cultural struggles, since it is they who must act to survive and "negotiate" between past and present, East and West. He writes that their struggles and histories "speak of the reality of survival and negotiation that constitutes the lived moment of resistance, its sorrow and its salvation-the moment that is rarely spoken in the stories of heroism that are enshrined in the histories we choose to remember and recount" (FB, p. 60; cf. LOC, p. 172).

Bhabha's performative politics are thus an implied critique of the "grand

(Footnote continued)

of the time of modernity" (LOC, pp. 244, 243). For an elaboration of this issue, see Nicholls, "Disrupting Time."

53 "Performing Politics," p. 325. 
politics" carried out by, and viewed from the perspective of, elites and the state. His is an attempt ${ }^{54}$ to democratize politics. In part, the goal is to widen the political terrain by capturing the myriad and daily forms of subjection, as well as the concomitant, "ordinary" acts of resistance. And in part, the goal is to "lower the sites" of politics, showing the "ordinary" to be extraordinary-nay, "spectacular"-as it reveals hegemonic or imperial power to be fractured and not as effective and totalizing as all that.

But what Bhabha leaves unclear is the extent to which localized agency can and does bring about meaningful change at the macro-levels of power (this is a problem he shares with the poststructuralist politics of Foucault). Although his work makes visible global or national power in the local, it is difficult to see how local agency, in turn, affects broader structures. His everyday and relatively informal and unorganized politics, coupled with his critique and comparative neglect of the nation-state and formal transnational structures, offer nothing in the way of coordinating mechanisms needed for sustained political transformation. Localized resistance may be multiple and widespread, but this does not necessarily translate into expansive change in hegemonic structures, or if it does then Bhabha does not demonstrate how. At a time of rapidly advancing and changing socio-economic globalization, the need for such coordinated political responses (whether through coalitional politics, community networking, or intersubjective deliberation) appears ever more pressing. I am not saying that Bhabha's performative politics are not amenable to a more complex politics, only that they appear incomplete in this respect. In fact, as Kulynych argues, they are not only amenable to, but can throw new light on, mainstream politics: performativity is "important not only for understanding the potential for innovation in the micro-politics of identity, but also for understanding the potential for innovation in an inter-subjective politics of deliberation ... Performative resistance is evident in intimate and personal relationships, in the deliberations of civil society, and in the problem-solving institutions of the constitutional state."

\section{Conclusion: An Innovative and Radical Politics?}

Meagan Vaughan declares that "To be 'discursively formulated' seems bad enough, but to be unstably discursively formulated looks like an impossible position from which to act." ${ }^{\prime 56}$ It does look like an impossible position, and yet as I have tried to show, Bhabha manages to negotiate it (for the most part). In many ways, his politics are captured by the two moments implied in Vaughan's remark: (1) an unstable discursive subjection which produces fractured identities and representations; and (2) the interpellation of a subject-as-agent who not only resists or responds to subjection but also exploits its discursive instabilities in favour of a supplemental, Third Space. Bhabha's gloss is innovative for showing that, despite being hegemonic, discourse's power precludes neither resistance/ agency nor the (critical) retrieval of indigenous representations. In this sense, his postcolonial examination of power reveals it to be more pervasive but also more

${ }^{54}$ Of course, he is building here on the pioneering work of the Subaltern Studies Collective, of which Spivak is part.

55 "Performing Politics," pp. 324, 327.

56 "Colonial Discourse Theory," p. 5. 
vulnerable than we are accustomed to thinking. His gloss is innovative as well for demonstrating that the instability and multiplicity of the subject never impedes, and in fact enables, political action. Thus, he suggests that the deconstructive critique of the (Enlightenment) subject need not get mired in political defeatism and, verily, can be recast to empower the subject. Notwithstanding its limits (i.e. its relative neglect of materiality, its privileging of informal over formal politics), this positive and creative Bhabhaian turn on agency, as I have underlined above, is an important advance on the poststructuralist politics of "resistance."

As for his radicality: there is, curiously enough, what may appear as a deeply conservative strain in Bhabha-his notion that politics can avoid revolutionary breaks, involve only slight alterations and happen only within discursive subjection looks decidedly traditionalist. Perhaps it is this strain that some of his critics are responding to. And yet, his politics are critical, subversive and transgressive. The paradox is compelling, without being just a Bhabhaian device: as we have registered, there are important reasons for having to work within discourse, which have principally to do with the dangers of opposing, reversing or cancelling power lest it be reproduced in new forms. That is why I must admit finding the paradox of acting within an imposed discourse or tradition, but still subverting its representational codes and producing new and unanticipated sites, compelling-and yes, radical. 